\title{
The need for rethinking the model of assessing value in the digital economy context
}

\author{
Cătălin Gabriel IONIȚĂ \\ PhD Candidate in Management \\ National University of Political Studies and Public Administration, Bucharest, Romania \\ catalin.ionita@facultateademanagement.ro
}

\begin{abstract}
In recent years, companies have begun to promote an economy based on knowledge and information, characterized by rapid economic changes, so the production of tangible goods has no longer been the main source of value, this being replaced by the creation and management of intangible assets, which are often not reflected in the accounting documents at the real market value because of the restrictive criteria for accounting valuation and recognition. Nowadays, the economy is based mainly on intangible assets and therefore they must be recognized in the financial statements of the companies, so that the shareholders and the investors have a clearer picture of company value. This paper aims to propose a model that can analyze the effects of intellectual capital and subcomponents of intangible assets on company value and the sustainable growth of firms listed on the Bucharest Stock Exchange. Until now, it is unknown which kind of sub-components of intangible assets make firms listed at Bucharest Stock Exchange to have sustainable growth or are more useful to enhance firm value. The proposed model includes data referring to intellectual capital, computerized information, innovative property, economic competences and VEKTOR index, which was developed by the Romanian Investor Relations Association so that the shareholders and the investors have a clearer picture of company when it comes to Relationship with Investors, Corporate Governance, Proactive Approach in IR, Interactive IR Instruments, Coverage by Financial Analysts and Sustainability.
\end{abstract}

Keywords: Intangible assets, Sustainable growth rate, Firm value, VEKTOR, Bucharest Stock Exchange.

\section{Introduction}

The economic and technological changes, together with the new means used by people for communication, such as smartphones and computers, have led our society on the verge of a digital revolution, characterized by large volumes of data, complex algorithms and innovative technological solutions, based on artificial intelligence, IOT and robotic process automation.

In recent years, companies have begun to promote an economy based on knowledge and information, characterized by rapid economic changes, so the production of tangible goods has no longer been the main source of value, this being replaced by the creation and management of intangible assets, which are often not reflected in the accounting documents at the real market value because of the restrictive criteria for accounting valuation and recognition. So, it is possible that accounting documents have become less informative regarding the actual and future value of a company, hence the traditional accounting model needs to be modified or at least expanded in order to reflect the "new" intangible assets and to improve the relevance of accounting information.

The process of value creation has undergone significant changes in recent years. As an example, Google with nearly 72,000 people has a market value of about 410 billion, while General Motors has a market value of 44 billion with approximately 225,000 employees. But what is really important to keep in mind is Google's accounting value of nearly $\$ 139$ billion,

DOI: $10.2478 /$ picbe-2020-0017, pp. 170-181, ISSN 2558-9652| Proceedings of the $14^{\text {th }}$ International Conference on Business Excellence 2020 
which is almost three times lower than the company's market value. In the case of General Motors, the difference is much smaller. Another relevant example is Skype, which at the time of sale to eBay in 2005, had an accounting value of about \$ 20 million but was sold for about \$ 2.6 billion, and in 2011 it was sold to Microsoft for about $\$ 8.5$ billion.

These examples show that the recognition of the intangible resources at the real value has become a major problem, both from the financial point of view and from the management point of view. Nowadays, the economy is based mainly on intangible assets and therefore they must be recognized in the financial statements of the companies, so that the shareholders and the investors have a clearer picture of company value.

This paper aims to propose a model that can analyze the effects of intellectual capital and subcomponents of intangible assets on company value and the sustainable growth of firms listed on the Bucharest Stock Exchange. Until now, it is unknown which kind of sub-components of intangible assets make firms listed at Bucharest Stock Exchange to have sustainable growth or are more useful to enhance firm value.

\section{Literature review}

\section{Intangible Assets}

In the literature, there are many definitions of intangibles assets. According to Mooney (2008), Siegel \& Shim (2000) and Andrews \& De Serres (2012), intangible assets have no physical substance and represent a right granted by the government or by another company. Also, Augier \&Teece (2005) define intangible assets as non-current assets and different from tangible (physical) assets because they are used by one party, their transfer costs are hard to calibrate, their property rights are limited, and the enforcement of property rights is relatively difficult (Ocak \& Findik, 2019).

According to Gardberg, (2006) and Wyatt (2005) there are many types of intangible assets such as patents, copyright, trademarks, design, mineral exploration, brand, software, formula, trade secrets, capitalized research and development, goodwill, databases, domain, human capital, motion pictures, consumer lists, customer loyalty, licenses, market share, and marketing rights. However, the most important intangible resources are represented by knowledge in all its forms (Bratianu \& Bejinaru, 2019, 2020; Edvinsson \& Malone, 1997).

According to International Accounting Standard 38, intangible assets should be identifiable, should be controlled by the firm, and should provide future economic benefits to the firm, and the cost of intangible assets can be measured reliably if firms report these kinds of items as an asset. In Romania, firms listed on Bucharest Stock Exchange should prepare their financial statements in accordance with the directions of the IASB. Thus, intangible investments made by firms are included in the financial statements of firms as an asset, if firms abide by the IASB's reporting criteria.

There are many studies that explore the effects of intangible assets or the sub-components of intangible assets or some types of specific intangible assets (such as patent, trademark, R\&D)on firm performance ( St-Pierre \& Audet, J, 2011; Villalonga, 2004; Denicoali, Zucchella, \& Strange, 2014;) on firm value (Megna \& Klock, 1993), on firm level and country level productivity (Dettori, Marrocu, \& Paci, 2012) on stock price (Ritter \& Wells, 2006) on economic growth (Fukao, Hamagata, Miyagawa, \& Tonogi, 2009). Recently there where published some studies focused on the relationship between firm governance structures and intangible assets and the sub-components of intangible assets (Ocak \& Findik, 2019). 
According to Ocak \& Findik (2019) nowadays companies invest more in intangible assets than in tangible assets because intangible assets play an effective role in sustaining a firm's competitive advantage (Villalonga, 2009) due to not being easy to imitate (Ocak \& Findik, 2019) and being an important determinant of firm internalization (Denicoali, Zucchella, \& Strange, 2014;). Software and R\&D are critical investments that sustain a firm's market presence in future years by reducing costs and increasing profits (Van Ark, Hao, Corrado, \& Hulten, 2009) so the sustainable growth of a firm can be considered a comprehensive mechanism to evaluate the longrun sustainability of a firm (Mukherjee \& Sen, 2018)

In this regard, intangible assets of firms may affect the sustainable growth of firms and it will be interesting to discuss the association between the intangible assets and sub-components of intangible assets classified by Corrado (2006) and the sustainable growth rate of firms. The main sources of intangible assets categorize by Corrado (2006) are:

-Computerized Information and Databases - knowledge embedded in computer programs and computerized databases;

-Innovative Property - strongly emphasizes the creation of new ideas and includes total cumulative amounts of capitalized research and development, copyrights, designs, licenses, and patents;

-Economic Competence - includes total cumulative amounts of trademarks, special costs, agreements, rights, customer lists, and dealer lists;

\section{Intangible Assets, Firm Value and Sustainable Growth}

There is an extant literature on the relationship between intangible assets and firm value, in industries such as on semiconductors, communications, food, pharmaceuticals and chemicals which is commonly measured as Tobin's. Megna \& Klock (1993) found that intangible capital is an important determinant of firm value and licenses and advertising contribute to the variation in communication industry.

$\mathrm{Wu}$ and Bjornson (1996) analyzed the effect of advertising activity in food industry and found that advertising activity positively affects the firm value. Gleason \& Klock (2004) found a similar pattern between intangible capital, which was proxied by R\&D and advertising activity, and firm value. Chin, Lee, Chi, \& Anandarajan (2006) revealed a positive and significant effect of patent citations on firms. However, Shane \& Klock (1997) used patent citations as an alternative indicator for intangible capital and detected a contrasting result to the previous evidence, patent citations do not have a significant effect on Tobin's Q.

According to Tseng \& James (2005) there is a positive relationship between intellectual capital and firm value, which is measured as Tobin's Q, market/book value, and value-added intellectual coefficient. For this research they used four types of intangible capital such as human capital, relationship capital, innovation capital, and organizational capital to construct intellectual capital. However, Salman, Mansor, Babatunde, \& Tayib, (2012) revealed that the effect of these subcomponents varies. For instance, the effect of human capital on firm value is larger than that of other types of capital. Firm value (FV) is measured as market value of assets divided by book value of assets.

(1)FV = Market value of assets/Book value of assets

DOI: $10.2478 /$ picbe-2020-0017,pp. 170-181, ISSN 2558-9652| Proceedings of the $14^{\text {th }}$ International Conference on Business Excellence 2020 
In the literature there are two well know developed models of sustainable growth, one proposed by de Higgins (1977) and the other proposed by Van Horne \& Wachowicz (2008). Also, there are two models of determination of sustainable growth rate: the first one is based on concepts developed by Higgins and the second one is developed on the concepts developed by Hamman (1996) and Churchill \& Mullins (2001), based on a cash flow model.

According to Amouzesh (2011), the sustainable growth rate represents a balanced

PICBE | 173 development direction of a company, indicating a way to grow without generating deficits or cash surpluses. Also, it indicates a maximum rate that a firm grows at relying on its own resources without using any financial tools outside the company (Ocak \& Findik, 2019). Fonseka studied Higgins and Van Horne models, finding that both are offering results that do not differ significantly, being equally preferred by researchers and managers (Fonseka et al. 2012). In case of Higgins the Sustainable Growth Rate (SGR) is equal to $\mathrm{P}^{*} \mathrm{R}^{*} \mathrm{~A}^{*} \mathrm{~T}$, where $\mathrm{P}$ is the profit margin, $\mathrm{R}$ is the retention rate, $\mathrm{A}$ is the asset turnover ratio, and $\mathrm{T}$ is the assets-to-equity ratio while in case of Van Horne the SGR is equal to ROE x Retention Ratio/1- ROE x Retention Ratio.

(2) SGR1 = Profit Margin $\times$ Asset Turnover $\times$ Retention Ratio $\times$ Financial Leverage (Higgins);

(3) $S G R 2=R O E \times$ Retention Ratio/1 - ROE $\times$ Retention Ratio (Van Horne);

Considering the relationship between intangible investment and sustainable growth, companies in general make a large amount of physical investment but they have difficulties with generating non-physical capital including intellectual capital, R\&D activities, and innovative activities (Yu \& Zhang, 2018). Intangible investment in various forms positively affects a firm's sustainable growth. A common form of intangible investment is intellectual capital which has a positive effect on financial performance of Korean manufacturing companies (Xu \& Wang, 2018).

Mukherjee \& Sen revealed that intellectual capital is an influencing factor for corporate sustainable growth as much as other factors, including physical capital, relational capital, innovation capital, and process capital. Moreover, Ying, Hassan, \& Ahmad, (2019) argued that intellectual capital affects sustainable growth of firms indirectly.

Liang, You, \& Liu (2010) emphasized the role of organizational capabilities such as developing new products and changing organizational structure to experience the performance enhancing effect of information technology. Mudambi (2011) and Demir \& Tolga (2014) found that R\&D activities positively affect firm growth. Furthermore, Xu \& Wang (2018) found that advertising stimulates $R \& D$ activities through increasing the reputation of the firms' current products and services. Ocak \& Findik (2019), developed a model that explores the effect of intangible assets and sub-components of intangible assets on sustainable growth and firm value in Turkey. They used data for companies listed on Istanbul Stock Exchange. In the proposed model, they did not include the data regarding intellectual capital. However, they include only the data referring to the subcomponents on intangible assets clasifield by Corado (2006).

The cumulative (i.e., aggregative) value of intangible assets of firms and sub-components of intangible assets were used as test variables. In addition, the proposed model included data that referred to board independency, board female percentage, CEO duality (Duality) and females in the top management level of firms.

DOI: $10.2478 /$ picbe-2020-0017, pp. 170-181, ISSN 2558-9652| Proceedings of the $14^{\text {th }}$ International Conference on Business Excellence 2020 
(4)SGRi,t or SGR2i,t. (or FVi,t) $=\_0+\ldots$ l Computerized Infoi, $t+\ldots 2$ Innovative Propertyi, $t+$ 3 Economic Competencei, $t+{ }_{-} 4$ Board Female Percenti, $t+{ }_{-} 5$ Board Independencei, $t$ + +_6 Dualityi $t+\ldots 7$ Top Female Percenti, $t+$ _ 8 Firm Sizei, $t+\ldots 9$ Leveragei, $t+\ldots 10$ Firm Performancei, $t+{ }_{-}^{-} 11$ Firm Agei, $t+\ldots 12$ Institutional Owneri, $t+$ SSector Dummies + SYear Dummies +

PICBE $\mid 174$

In the model, firm size is the natural logarithm of total assets of a firm, leverage is calculated as the total debts divided by total assets, financial performance is measured as net income divided by total assets, firm age is the natural logarithm of the number of years since establishment, institutional ownership is the percentage of total shares of institutional owners. Computerized information and databases (Computerized Info) and economic competence (Economic Competence) are positively and significantly related to the rates of sustainable growth and are positively and significantly associated with firm value. Even though the proposed model showed the correlation between sustainable growth, firm value and different sub-components of intangible assets, it has some evident limitation because it does not include any information related to the intellectual capital, which play an important role in sustainable growth rate for companies.

\section{Intellectual capital and VAIC model}

According to Barney (1991) intelectual capital is considered a driver of corporate competitiveness, financial sustainability and firm value creation, through the dynamic set of resources such as: knowledge, capabilities, networks, operation processes, individual and organizational relations (Demartini \& Trucco, 2016). Ujwary-Gil (2017) and Peteraf \& Barney (2003) believed that companies with valuable and scarce resources are more likely to obtain sustainable competitive advantage. These resources can enable companies to maintain human capital, improve processes, maintain contact with customers and suppliers, and produce greater innovation (Jardon \& Martos, 2012).

Even though in the early studies the intellectual capital was comprised of human capital and structural capital (Edvinsson \& Malone, 1997), nowadays researchers achieved to a consensus on the components of intellectual capital, namely human capital, structural capital and relational capital (Sveiby, 1997; Bontis, 2001; Sydler, Haefliger, \& Pruksa, 2014; Nimtrakoon, 2015; Sardo \& Serrasqueiro, 2018). For measuring intellectual capital, researchers developed several methods such as: Skandia Navigator (Edvinsson \& Malone, 1997), the Intangible Assets Monitor (Sveiby, 1997), the balanced scorecard approach (Kaplan \& Norton, 1996) and the Value-Added Intellectual Coefficient (Pulic, 2000). The VAIC model was proposed to measure the efficiency of firms' three types of inputs: physical capital, HC, and SC, namely, capital employed efficiency (CEE), human capital efficiency (HCE), and structural capital efficiency (SCE). The sum of CEE, HCE, and SCE is the value of VAIC (Xu \& Wang, 2018).

Researchers have studied how IC is linked to firms' financial performance. RiahiBelkaoui (2003) documented a significant and positive relationship between IC and financial performance while Firer \& Williams (2003) showed a positive relationship between IC and the performance of South African firms. Also, Tan et al (2007) argued that IC can positively improve the firms' present and future performance. Moreover, Phusavat, Comepa, Sitko-Lutek, \& Ooi (2011) ound a positive relationship between IC and profitability, revenue growth and employee 
productivity. In addition, Sardo \& Serrasqueiro (2017) argued that companies should take advantage of IC to boost firm's financial performance and market value. Investors may place different values on each component of VAIC. CEE is used to measure the physical capital dimension. HCE and SCE are the measurements of the value-added efficiency by $\mathrm{HC}$ and SC, respectively. By applying the VAIC model, Mavridis (2004) concluded that HC has the highest degree of correlation with the performance of Japanese banks. Kamath (2008) asserted that HC is more important than physical capital and SC in terms of their impact on the profitability and productivity of the Indian pharmaceutical industry. Also, Nimtrakoon (2015) argued that SCE is positively correlated with firms' market value.

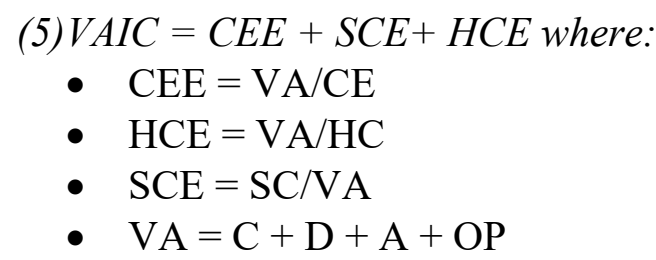

It is important to mention that VAIC model does not include innovative capital and RC in its calculation. However, researchers have provided evidence on the value-relevance of R\&D and advertising expenditures. Chauvin \& Hirschey (1993) concluded that both type of expenditures has positive influences on corporate market value while Sullivan (1998) found that innovative capital, the core of IC, can provide the base for obtaining competitiveness.

$\mathrm{Xu}$ and Wang (2018) investigate the relationship between sustainable growth rate and the aggregate measure of VAIC and its three components, respectively. In the proposed model they introduced firm size and debt ratio as control variables. Firm size (SIZE), was measured as the natural logarithm of total assets at year-end, and debt ratio (LEV), was measured by total debt to its total assets. The proposed model by to XU and Wang (2018) determine the relationship between sustainable growth rate and the aggregate measure of VAIC as is presented below:

$$
\text { (6) SGRi,t }=\beta 0+\beta 1 C E E i, t+\beta 2 H C E i, t+\beta 3 S C E i, t+\beta 4 S I Z E i, t+\beta 5 L E V i, t+\varepsilon i, t
$$

Findings of the above model suggest that VAIC has a positive impact on firm performance indicators (ROA and ROE), stating that intellectual capital can positively enhance firms' financial performance and generate wealth in South Korea, an emerging market. Results also show that intellectual capital positively affects companies' sustainable growth. This provides evidence consistent with the findings of Smriti \& Das (2018) and Chen (2005) who stated that IC has a positive impact on revenue growth.

The model has evident limitation because it includes only data referring to intellectual capital, firm size and debt ratio. A good model that measures the sustainable growth rate, has to include data referring to knowledge embedded in computer programs and computerized databases, copyrights, designs, licenses and patents, trademarks, special costs, agreements, rights, customer lists, and dealer lists.

\section{Methodology}




\section{Model proposed for the companies listed at Bucharest Stock Exchange.}

The models presented during this paper are not sufficiently comprehensive to analyze the effect of intangible resources on firm value and the sustainable growth of companies. In the model proposed by Xu \& Wang (2018), it was included only a part of the intangible resources, namely intellectual capital. While in the model proposed by Ocak \& Findik (2019), it was included subcomponents of intangible resources such as Computerized Information and Databases, Innovative Property, and Economic Competence, but intellectual capital was excluded.

This paper aims to propose a model that can analyze the effects of intellectual capital and subcomponents of intangible assets, categorized by Corado (2006) on company value and the sustainable growth of firms listed on the Bucharest Stock Exchange. Until now, it is unknown which kind of sub-components of intangible assets make firms listed at Bucharest Stock Exchange to have sustainable growth or are more useful to enhance firm value.

Starting with January 2020, the Association for Investor Relations with the Romanian Stock Exchange publish the VEKTOR index for the listed companies on the Regulated Market at the Bucharest Stock Exchange. The index is calculated based on a methodology that includes fifteen criteria, in line with international best practices in investor relations (IR).

The criteria based on which the indicator is determined divided into five main sections (relationship with investors; corporate governance; proactive approach in IR; interactive IR instruments; coverage by financial analysts; sustainability) and include information regarding: the availability of the investor relations team; information on company management and remuneration policy; organizing telephone conferences dedicated to financial results; the existence of a presentation for investors; publication of press releases related to financial reporting; participation in events with investors; provision of financial information in excel format; transcript / recording conferences to present financial results; publication of data on the price of the action; coverage by financial analysts; non-financial reporting.

(7) VEKTOR $=\beta 1$ Relationship with Investors $+\beta 2$ Corporate Governance $+\beta 3$ Proactive Approach in IR $+\beta 4$ Interactive IR Instruments $+\beta 4$ Coverage by Financial Analysts $+\beta 6$ Sustainability

The below model is utilized to investigate the effect of the cumulative value of intangible assets of firms on sustainable growth rate and firm value the companies listed at Bucharest Stock Exchange.

\section{(8)SGRi,t or FVi,t $=\beta 0+\beta 1 V A I C+\beta 2$ Intangible assets $+\beta 3 V E K T O R$}

The below model is utilized to estimate the effect of each sub-component of intangible assets on sustainable growth rate and firm value of the companies listed at Bucharest Stock Exchange. Also, the model shows which sub-component of intangible assets is more critical in improving sustainable growth and firm value.

(9)SGRi,t or FVi, $=\beta 0+\beta 1 C E E i, t+\beta 2 H C E i, t+\beta 3$ SCEi,$t+\beta 4$ SIZEi $, t+\beta 5 L E V i, t+$ $\beta 6$ Computerized Infoi,t $+\beta$ IInnovative Propertyi, $t+\beta 8$ Economic Competencei, $t+$ $\beta 9$ Relationship with Investors $+\beta 10$ Corporate Governance $+\beta 11$ Proactive Approach in IR $+\beta 12$ Interactive IR Instruments $+\beta 13$ Coverage by Financial Analysts $+\beta 14$ Sustainability 
For the companies listed on the Bucharest Stock Exchange, information regarding the components of intangible assets is located in the footnotes of financial statements. From these documents can be extracted valuable information regarding the type of intangible assets in which the company invests. Then the data can be classified in the subcomponents recommended by Corado (2006). Moreover, the Bucharest Stock Exchange provides its members with registration, settlement, and custody services. Besides, it includes information regarding the ownership structures, dividend payments, and public offerings of the listed companies. Furthermore, starting with January 2020, Bucharest Stock Exchange provides information regarding the corporate governance structures of listed companies through the VEKTOR index.

\section{Conclusion}

Managers of firms should take into account the importance of intangible assets for sustainable growth and firm value, and thus, they should know that more investment in these kinds of strategic assets will increase the success of a firm. Additionally, investing in these assets will necessitate changes in the organization of the work. For instance, some specific operations that require a long time to complete will be implemented in a shorter time; thus, firms will be able to discover new markets. The proposed model has some limitations because it uses data of the companies listed Bucharest Stock Exchange. As it is known, the listed companies on the Bucharest Stock Exchange are those that have good financial performances to match the requirements of the regulated market, and growth is, for most of them, a must. Besides, the data necessary for the proposed model can be reached easily because Bucharest Stock Exchange make them public. Until now the proposed model has not been tested because the VEKTOR index was first published in January 2020 and in order to test the model it is needed that VEKTOR index to be reported at least twice.

In the case of small and medium-sized companies that are not listed at the Bucharest Stock Exchange, the model will be hard to be applied due to missing information, and in many cases, these are hard to reach. Future research may focus on testing the proposed model and then to replicate it for the SMEs not listed at the Bucharest Stock Exchange, to check if the model is valid for non-listed companies.

\section{References}

Pulic, A. (2000). VAICTM-an accounting tool for IC management. International Journal of Technology Management, 20, 702-714.

Amouzesh, N. (2011). Sustainable growth rate and firm performance: evidence from Iran stock exchange. International Journal of Business and Social Science, 2(23), 249-255.

Andrews, D., \& de Serres, A. (2012). Intangible assets, resource allocation and growth: A framework for analysis. Working Pap, OECD, Economic Department.

Augier, M., \& Teece, D. (2005). An economic perspective on intellectual capital. In B. Marr (Ed.), In Perspective on Intellectual Capital: Multidisciplinary Insight into Management, Measurement, and Reporting. 1th Ed, pp. 3-27. Oxford: Elsevier Inc. 
Barney, J. (1991). Firm resources and sustained competitive advantage. Journal of Management, 17, 99-120.

Bontis, N. (2001). Assessing knowledge assets: A review of the models used to measure intellectual capital. International Journal of Management Reviews, 3(1), 41-60.

Bratianu, C., \& Bejinaru, R. (2019). The theory of knowledge fields: a thermodynamics

PICBE | 178 approach. Systems, 7(2), 20, 1-12.

Bratianu, C., \& Bejinaru, R. (2020). Knowledge dynamics: a thermodynamics approach. Kybernetes, 49(1), 6-21.

Chauvin, K., \& Hirschey, M. (1993). Advertising, R\&D expenditures and the market value of the firm. Finance Mangement, 22, 128-140.

Chin, C., Lee, P., Chi, H., \& Anandarajan, A. (2006). Patent citation, R\&D spillover, and Tobin's Q: Evidence from Taiwan semiconductor industry. Review of Quantitative Finance and Accounting, 26, 67-84.

Churchill, N., \& Mullins, J. (2001). How fast can your company afford to grow. Harvard Business Review, 79(5), 135-143.

Demartini, C., \& Trucco, S. (2016). Does intellectual capital disclosure matter for audit risk? Evidence from the UK and Italy. Sustainability, 8, 867-774.

Demir, K., \& Tolga, I. (n.d.). A sustainable growth rate metric based on R\&D experience for government R\&D organizations. Journal Of Global Strategic Management, 8(2), 27-37.

Denicoali, S., Zucchella, A., \& Strange, R. (2014). Knowledge assets and firm international performance. International Business Review, 23, 55-62.

Dettori, B., Marrocu, E., \& Paci, R. (2012). Total factor productivity, intangible assets and spatial dependence in the European regions. Regional Studies, 46, 1401-1416.

Edvinsson, L., \& Malone, M. (1997). ntellectual Capital: Realizing Your Company's True Value by Finding Its Hidden Brainpower. New York, USA: Harper Business.

Find1k, D., \& Ocak, M. (2019). Gender diversity and independency: Threat or opportunity in managing innovative property? (Vol. 1th ed). (H. Dinçe, \& S. Yüksel, Eds.) Hershey, PA, USA: IGI Global.

Firer, S., \& Williams, M. (2003). Intellectual capital and traditional measures of corporate performance. Journal of Intellectual Capital, 4, 348-360.

Fonseka, M., Ramos, C., \& Tian, G. (2012). he most appropriate sustainable growth rate model for managers and researchers. Journal of Applied Business Research, 28(3), 481-500.

Fukao, K., Hamagata, S., Miyagawa, T., \& Tonogi, K. (2009). Intangible investment in Japan: Measurement and contribution to economic growth. Review of Income and Wealth, 55, 717-736.

Gardberg, N., \& Fombrun, C. (2006). Corporate citizenship: Creating assets across institutional environments. Academic Management Review, 31, 329-346. 
Hamman , W. (1996). Sustainable growth: A cash flow model. Investment Analysts Journal, 43, 57-61.

Higgins, R. (1977). How much growth can a firm afford? Finance Mangement, 6(3), 7-16.

Jardon, C., \& Martos, M. (2012). Intellectual capital as a competitive advantage in emerging clusters in Latin America. Journal of intellectual capital, 13, 462-481.

PICBE $\mid 179$

Kamath, G. (2008). Intellectual capital and corporate performance in Indian pharmaceutical industry. Journal of Intellectual Capital, 9, 684-704.

Kaplan, R., \& Norton, D. (1996). The Balanced Scorecard: Translating Strategy into Action. Boston, USA: Harvard Business Press.

Liang, T., You, J., \& Liu, C. (2010). A resource-based perspective on information technology and firm performance: A meta analysis. Industrial Management \& Data Systems, 110, $1138-1158$.

Mavridis, D. (2004). The intellectual capital performance of the Japanese banking sector. Journal of Intellectual Capital, 5, 92-115.

Megna, P., \& Klock, M. (1993). The impact of intangible capital on Tobin's q in the semiconductor industry. American Economic Review, 83, 265-269.

Megna, P., \& Klock, M. (1993). The impact of intangible capital on Tobin's q in the semiconductor industry. American Economy Review, 83, 265-269.

Mooney, K. (2008). The Essential of Accounting Dictionary. Naperville, IL, USA: Sphinx Publishing.

Mudambi, R., \& Swift, T. (2011). Proactive R\&D management and firm growth: A punctuated equilibrium model. Research Policy, 40(3), 429-440.

Mukherjee, T., \& Sen, S. (2018). Sustainable growth rate and its determinants: A study on some selected companies in India. Global Multidisciplinary, 10(1), 100-108.

Mukherjee, T., \& Sen, S. (2019). Intellectual Capital and Corporate Sustainable Growth: The Indian Evidence. The Journal of Business, Economics, and Environmental Studies, 9, 515.

Nimtrakoon, S. (2015). The relationship between intellectual capital, firms' market value and financial performance: empirical evidence from the ASEAN. Jpurnal of Intellectual capital, 16, 587-618.

Nimtrakoon, S. (2015). The relationship between intellectual capital, firms' market value and financial performance: empirical evidence from the ASEAN. Journal of Intellectual Capital, 16, 587-618.

Peteraf, M., \& Barney, J. (2003). Unraveling the resource-based tangle. Managerial and Decision Economics, 24, 309-323.

Phusavat, K., Comepa, N., Sitko-Lutek, A., \& Ooi, K. (2011). Interrelationships between intellectual capital and performance: empirical examination. Industrial management data System, 810-829.

DOI: 10.2478/picbe-2020-0017, pp. 170-181, ISSN 2558-9652| Proceedings of the $14^{\text {th }}$ International Conference on Business Excellence 2020 
Riahi-Belkaoui, A. (2003). Intellectual capital and firm performance of US multinational firms: A study of the resource-based and stakeholder views. Journal of Intellectual Capital, 4, 215-226.

Ritter, A., \& Wells, P. (2006). Identifiable intangible asset disclosures, stock prices and future earnings. Accounting finance, 46, 843-863.

Salman, R., Mansor, M., Babatunde, A., \& Tayib, M. (2012). Impact of intellectual capital on return on asset invNigerian manufacturing companies. Information and Knowledge Management, 2, 21-3-.

Sardo, F., \& Serrasqueiro, Z. (2017). European empirical study of the relationship between firms' intellectual capital, financial performance and market value. Journal of Intellectual Capital, 18, $771-788$.

Sardo, F., \& Serrasqueiro, Z. (2018). Intellectual capital, growth opportunities, and financial performance in European firms: Dynamic panel data analysis. Journal of Intellectual Capital, 19, 747-767.

Shane, H., \& Klock, M. (1997). The relation between patent citations and Tobin's Q in the semiconductor industry. Review of Quantitative Finance and Accounting volume, 9, 131146.

Siegel, J., \& Shim, J. (2000). Dictionary of Accounting Terms (Vol. 1th ed). New York, NY, USA: Barron's Educational Series.

St-Pierre, J., \& Audet, J. (2011). Intangible assets and performance: Analysis on manufacturing SMEs. Journal of Intellectual capital, 12, 202-223.

Sullivan, P. (1998). Profiting from Intellectual Capital: Extracting Value from Innovation. New York, USA: Wiley.

Sveiby, K. (1997). he New Organizational Wealth: Managing and Measuring Knowledge- Based Assets. San Francisco, USA: Berrett-Koehler Publishers.

Sydler, R., Haefliger, S., \& Pruksa, R. (2014). Measuring intellectual capital with financial figures: Can we predict firm profitability? European Management Journal, 32, 244-259.

Tan, H., Plowman, D., \& Hancock, P. (2007). Intellectual capital and financial returns of companies. Journal of Intellectual Capital, 8, 76-95.

Tseng, C., \& James Goo, Y. (2005). Intellectual capital and corporate value in an emerging economy: Empiricalvstudy of Taiwanese manufacturers. R\&D Management, 35, 187-201.

Ujwary-Gil, A. (2017). The business model and intellectual capital in the value creation of firms: A literature review. Baltic Journal of Management, 12, 368-386.

Van Ark, B., Hao, J., Corrado, C., \& Hulten, C. (2009). Measuring intangible capital and its contribution to economic growth in Europe. EIB Papers, 14, 62-93.

Van Horne, J., \& Wachowicz , J. (2008). Fundamentals of Financial Management (Vol. 13th edition). Prentice-Hall. 
Villalonga, B. (2004). Intangible Resources, Tobin's q, and sustainability of performance differences. Journal of Economic Behaviour, 54, 205-230.

Wu, Q., \& Bjornson, B. (1996). Value of advertising by food manufacturers as investment in intangible capital. Agribusiness, 12, 147-156.

Wyatt, A. (2005). Accounting recognition of intangible assets: Theory and evidence on economic determinants. Accounting review, 80, 967 - 1003.

Xu, J., \& Weng, B. (2018). Intellectual capital, financial performance and companies' sustainable growth: Evidence from the Korean manufacturing industry. Sustainability, 10(1).

Ying, Q., Hassan, H., \& Ahmad, H. (2019). The role of a manager's intangible capabilities in resource acquisition and sustainable competitive performance. Sustainability, 11, 527534.

Yu, F., \& Zhang, L. (2018). Does intellectual capital really create value? IEEE 4th International Conference onWireless Communications, Networking and Mobile Computing,. Sydney, Australia. 